\title{
Childhood Morbidity and its Association with Socio-economic and Health Care Condition among Under 5 Years Children in West Bengal: An Evidence from NFHS-5, 2019-20
}

\author{
Koustav Ghosh ${ }^{1,2, *}$, Shoummo Sen Gupta ${ }^{3}$, Atreyee Sinha Chakraborty ${ }^{1}$
}

\section{Koustav Ghosh ${ }^{1,2, *}$, Shoummo Sen Gupta ${ }^{3}$, Atreyee Sinha Chakraborty ${ }^{1}$ \\ ${ }^{1}$ Gokhale Institute of Politics and Economics (GIPE), Pune, Maharashtra, INDIA. \\ 2Population Research Centre (PRC), Vadodara, Gujarat, INDIA. IInternational Institute for Population Sciences (IIPS), Mumbai, Maharashtra, INDIA. \\ Correspondence \\ Mr. Koustav Ghosh \\ Ph.D Research Scholar, Gokhale Institute of Politics and Economics (GIPE), \\ Pune-411004, Maharashtra, INDIA. \\ Mobile no: +91-8101008044 \\ Email: koustav2020@gmail.com \\ History \\ - Submission Date: 19-03-2021; \\ - Revised Date: 28-04-2021; \\ - Accepted Date: 08-07-2021;}

DOI : 10.5530/ijmedph.2021.3.29

Article Available online

http://www.ijmedph.org/v11/i3

\section{Copyright}

(C) 2021 Phcog.Net. This is an openaccess article distributed under the terms of the Creative Commons Attribution 4.0 International license.

\begin{abstract}
Introduction: Child health issue is a public health concern in India and the country has already set its goal to achieve sustainable development goals (SDGs) target to reduce under-five mortality to 25 per 1000 live births by 2030. A good socio-economic condition and health care facility can reduce child morbidity and mortality. Objectives: The present study aims to show the pattern of morbidity among under-five children and its association with socio-economic and health care condition in West Bengal. Materials and Methods: This study has been carried out from district level fact-sheets of NFHS-5 (2019-20). Dimension Indices (DI) are developed for the indicators of child morbidity, health care and socio-economic status. Bivariate analyses are performed using Spearman's rank correlation coefficient and Pearson's correlation coefficient. Multivariate analyses are carried out using simple linear regression model. Results: Results show Purulia district of West Bengal represents a highest level of child morbidity and North Twenty-Four Parganas district as a low level of child morbidity status ; whereas, both districts show reverse status in the case of socio-economic and health care context. Spearman's rank correlation coefficient of child morbidity is negatively related with socio-economic $(-0.54)$ and health care status $(-0.62)$ and in both the cases they are significantly different from zero $(P<0.05)$. Availability of electricity, women literacy, improved sanitation facility and child immunization are negatively correlated with child morbidity. Conclusion: The study recommends targeting the districts with high child morbidity, poor socio-economic and health care status and suggest improvements to reduce the same by facilitating improved sanitation facility, increase in women literacy and full immunization.
\end{abstract}

Key words: Child Health, Morbidity, Mortality, Under-five Child, Socio-economic condition, Health care status.

\section{INTRODUCTION}

Child health and nutritional status is a major public health issue in the world as they play an important role in overall development and wellbeing of children. ${ }^{1,2}$ The latest report of United Nations International Children's Emergency Fund (UNICEF) revealed that malnourishment (45\%), Pneumonia (15\%), diarrhoea (8\%), malaria (5\%) and others (9\%) are major responsible causes for the death of under children in the world. ${ }^{3}$ Moreover, malnutrition reduces immunity and causes increased vulnerability to infections like diarrhoea ${ }^{3-5}$ and which are globally the common causes of morbidity and mortality specially among under-five years children. ${ }^{6}$ Every year globally 2.5 million children die due to diarrhoea ${ }^{7,8}$ and 3 million children die due to malnutrition. ${ }^{9}$ In this context different studies point out socioeconomic conditions and education level of the parents have a significant impact on child nutritional status. ${ }^{10}$ A study by Mallick, 2021 shows that socioeconomic variable and health care services have a negative relation with child morbidity. ${ }^{11}$ The National
Family Health Survey (NFHS) shows slow decrease in the prevalence of malnutrition and Acute Respiratory Infection (ARIs) among children in India from 2006 to 2016 but the prevalence of diarrhoea has been increased at the same time. ${ }^{12,13} \mathrm{ARI}$ and diarrhoea are the major causes of morbidity and mortality among under-five children in developing country such as India. $^{8,14}$

The present data shows that in the developing counties, on an average under 5 children suffer from diarrhoea three times in a year ${ }^{15}$ whereas for ARI its four to five times in a year. ${ }^{16}$ It has been found that ARI was the most frequent reason for morbidity $(38.6 \%)$, followed by under nutrition $(27.7 \%)$, pallor (27.7\%), worm infestation (14.9\%), skin disease (12.8\%) and diarrhoea (12.8\%) respectively in rural West Bengal. ${ }^{17}$ Improved literacy status of the mother, better housing condition and adequate knowledge of exclusive breast feeding may help to reduce the morbidity among under-five children in West-
Cite this article : Ghosh K, Sen Gupta S, Chakraborty Sinha A. Childhood Morbidity and its Association with Socio-economic and Health Care Condition among Under 5 Years Children in West Bengal: An Evidence from NFHS-5, 2019-20. Int J Med Public Health. 2021;11(3):160-3. 
Bengal. ${ }^{17}$ Knowledge related to ARI may help in reduction of the risk of U-5 morbidity as well as mortality. ${ }^{18,19}$

Child health is a public health concern in India and the country has already set its goal to achieve SDGs target to reduce under five child mortality by 25 per 1000 live births in 2030 (SDGs) which is 50 per 1000 live births as per National Family Health survey. ${ }^{13,20}$ To achieve the Millennium development Goal-4 (MDG), and to reduce the child mortality, Government of India has launched various programme and schemes like child survival and safe motherhood programme (1992), target-free approach (1996), reproductive and child health programme (RCH) (1997 and 2005), national rural/urban health mission (between 2005 and 2012), national health mission (NHM), (2013 to-date), programme related to immunization and prevent diarrheal disease and ARI. The comparison between NFHS-4 (2015-16); NFHS-3 (2005-06) shows that under-five mortality rate (U-5MR) has been reduced from 74 to 50 and infant mortality rate (IMR) has been decreased from 57 to 41 per 1000 livebirths between 2006 and 2016..$^{12,13,21}$

According to NFHS, in West Bengal the prevalence of ARI has been reduced from $3.3 \%$ in $2015-16$ (NFHS-4) to $2.8 \%$ in $2019-20$ (NFHS5). ${ }^{13,22}$ In the case of diarrhoea, there is an increase from $5.9 \%$ to $6.5 \%$ in the same time. Similarly, malnutrition status related to stunting, wasting, and underweight also shows that an increasing trend from 2015-16 to 2019-20 (NFHS-4, 2015-16; NFHS-5, 2019-20). ${ }^{13,22}$ The prevalence of childhood morbidity and mortality is a major public health concern in West Bengal and India as a whole.

Given the slow rate of decline in ARI, and increased prevalence of malnutrition and diarrhoea among children, the present study has been conducted to estimate the pattern of morbidity among underfive children and its association with socio-economic and health care conditions in West Bengal, based on newly release NFHS-5 fact sheet.

\section{MATERIALS AND METHODS}

\section{Data}

The study uses National Family Health Survey (NFHS-5) fact sheet data of India, 2019-20. This national level large-scale survey was conducted by the Ministry of Health and Family Welfare, Government of India and International Institute for Population Sciences (IIPS), Mumbai, a nodal agency for that survey.

\section{Methodology}

The indices of health (morbidity) status, health care and socio-economic status are obtained by the Dimension Index (DI) developed by Iyengar and Sudarshan. ${ }^{11}$ The definition of the DI is the index value lying between 0 and 1. Greater value indicates the good development in the case of socio-economic and health care but in the case of child health (morbidity) status greater the value indicates the more vulnerable child health condition.

Dimension Index $(D I)=\frac{X_{\mathrm{id}}-X_{\mathrm{idmin}}}{\mathrm{X}_{\mathrm{idmax}}-\mathrm{X}_{\mathrm{idmin}}}$

\section{Socio-Economic Condition}

The socio-economic factors considered are availability of electricity, availability of safe drinking water, improved sanitation facility, use of clean fuel, health insurance coverage and women literacy rate. The socioeconomic composite index is obtained by adding the dimension indices of the components of socio-economic status. A highest composite score represents a good socio-economic status and lowest as a poor socioeconomic status.

\section{Health Care Condition}

The health care factors include use of family planning methods, antenatal care, institutional births and full immunization. The composite indices of health care factors are obtained by adding the dimension indices of the health care factors. A higher composite score represents a good health care services and lower index represents a poor health care service.

\section{Childhood Morbidities}

The child morbidities include prevalence of diarrhoea, ARI, stunting, wasting and underweight. The composite index of health (morbidity) status is obtained by adding the dimension indices of the health status factors.

\section{Statistical Analyses}

Spearman's rank correlation coefficient between the health status (child morbidity) DI and socio-economic DI was obtained to study the correlation between those indices. Similarly, the correlation between health status DI and health care DI was studied using spearman's rank correlation coefficient. Bivariate analysis was also carried out by obtaining the Pearson correlation coefficient between the health status composite index (or child morbidity index) and dimension indices of several components of socio-economic status and health care condition. The determinants of health status were obtained through a simple linear regression of health status composite index on the DIs of several socioeconomic factors and health care factors (Table 1).

\section{RESULTS AND DISCUSSION}

Geographical variation of Socio-economic condition, health care condition and morbidity among children age under-fives years: Table 2 describes the health care status and the child morbidity among the districts of West Bengal in 2019-20. In the case of socio-economic condition North Twenty-Four Parganas represents elevated socioeconomic condition in the districts of West Bengal followed by South Twenty-Four, Kolkata, Koch Bihar and Haora. On the contrary, Puruliya,

\section{Table 1: Pearson's Correlation Coefficient between Child morbidity and} different factors.

\begin{tabular}{|c|c|c|}
\hline $\begin{array}{l}\text { Socio-economic Dimension } \\
\text { Index }\end{array}$ & Correlation Coefficient & $P$ value \\
\hline Availability of Electricity & $-0.63^{*}$ & 0.003 \\
\hline $\begin{array}{c}\text { Availability of Safe Drinking } \\
\text { Water }\end{array}$ & -0.27 & 0.252 \\
\hline Improved sanitation Facility & $-0.79^{*}$ & 0.000 \\
\hline Use of Clean Fuel & -0.19 & 0.432 \\
\hline Health Insurance Coverage & 0.14 & 0.566 \\
\hline Women Literacy Rate & $-0.63^{*}$ & 0.003 \\
\hline Health care Dimension Index & & \\
\hline Use of Family Planning Method & -0.37 & 0.113 \\
\hline Antenatal care & -0.43 & 0.057 \\
\hline Institutional births & -0.44 & 0.051 \\
\hline Fully Immunization & $-0.55^{*}$ & 0.012 \\
\hline
\end{tabular}

Source: Authors' calculation from NFHS-5 (2019-20) Fact Sheet. 
Purba Medinipur, Paschim Medinipur, Uttar Dinajpur and Bankura have reported lower socio-economic status in West Bengal.

On the other hand, North Twenty Four Parganas, Darjeeling, Jalpaiguri, South Twenty Four Parganas, Howrah and Koch Bihar districts indicate the prevalence of elevated health care services whereas Purulia, Paschim Medinipur, Paschim Barddhaman, Purba Medinipur, Uttar Dinajpur and Bankura districts show decreased health care service status in West Bengal.

The child morbidity is highest in Purulia followed by Birbhum, Bankura, Paschim Barddhaman, Uttar Dinajpur and Paschim Medinipur, whereas North Twenty Four Parganas, Koch Bihar, Jalpaiguri, Nadia, Dakshin Dinajpur and Purba Medinipur represent low child morbidity in West Bengal.

Table 2 and Table 3 indicate the order of the districts sorted by child morbidity. The spearman's rank correlation coefficient between health care and child morbidity is -0.54 and is significantly different from 0 $(P=0.014)$. The spearman's rank correlation coefficient between child morbidity and socio-economic status is -0.62 which is also significantly different from $0(P=0.004)$ (Table 3$)$.

Table 1 depicts the association between the socio-economic condition and availability of health care services with child morbidity using the correlation coefficient.

Results show that there is a linear relationship between child morbidity with availability of electricity (Correlation Coefficient: $-0.63 ; P=0.003$ ), improved sanitation (Correlation Coefficient: $-0.79 ; \quad P<0.001$ ), women's literacy rate (Correlation Coefficient: $-0.63 ; p=0.003$ ), and

Table 2: Dimension Index for socio-economic, health care status and child morbidity among under 5 children of the various districts of West Bengal.

\begin{tabular}{|c|c|c|c|}
\hline \multirow[b]{2}{*}{ Districts } & \multicolumn{3}{|c|}{ Composite Score } \\
\hline & $\begin{array}{c}\text { Socio- } \\
\text { Economic } \\
\text { Condition }\end{array}$ & $\begin{array}{l}\text { Health Care } \\
\text { Status }\end{array}$ & $\begin{array}{l}\text { Child } \\
\text { Morbidity }\end{array}$ \\
\hline Bankura & 2.7 & 2.1 & 3.4 \\
\hline Birbhum & 3.5 & 2.7 & 3.6 \\
\hline Dakshin Dinajpur & 3.6 & 2.9 & 1.5 \\
\hline Darjeeling & 3.7 & 3.5 & 2.2 \\
\hline Haora & 4.1 & 3.4 & 2.2 \\
\hline Hugli & 4.0 & 3.0 & 1.9 \\
\hline Jalpaiguri & 3.7 & 3.5 & 1.1 \\
\hline Koch Bihar & 4.2 & 3.2 & 0.9 \\
\hline Kolkata & 4.6 & 2.9 & 2.3 \\
\hline Maldah & 3.4 & 2.7 & 2.3 \\
\hline Murshidabad & 3.2 & 2.6 & 2.2 \\
\hline Nadia & 3.6 & 2.5 & 1.3 \\
\hline North Twenty Four Parganas & 4.8 & 3.6 & 0.6 \\
\hline Paschim Barddhaman & 3.2 & 1.4 & 3.1 \\
\hline Paschim Medinipur & 2.4 & 1.4 & 2.5 \\
\hline Purba Barddhaman & 3.7 & 3.1 & 2.2 \\
\hline Purba Medinipur & 2.4 & 1.7 & 1.7 \\
\hline Puruliya & 0.7 & 1.3 & 3.9 \\
\hline South Twenty Four Parganas & 4.6 & 3.4 & 1.8 \\
\hline Uttar Dinajpur & 2.7 & 1.9 & 2.8 \\
\hline
\end{tabular}

full immunization (Correlation Coefficient: -0.55; $P=0.012$ ). All mentioned are negatively correlated with child morbidity. Every unit of elevated electricity, improved sanitation, women's literacy rate and full Immunization help to reduce $0.63,0.790 .63$ and 0.55 unit of child morbidity in West Bengal.

To examine the association between the socio-economic conditions and availability of health care services with child morbidity linear regression was used with variables related to socio-economic and health care dimension indices to understand their effect on composite score value of child morbidity. Table 4 shows the results of regression analysis using two models. In model one, no significant relationship has been found

\section{Table 3: Sprearman's Rank Correlation Coefficient with child morbidity.}

\begin{tabular}{ccc}
$\begin{array}{c}\text { Socio-Economic condition and health care } \\
\text { status }\end{array}$ & Coefficient & P value \\
\hline Health Care Socio-Economic Condition & -0.54 & 0.014 \\
Health Care Status & -0.62 & 0.004
\end{tabular}

Table 4: Determinants of Child morbidity by using Simple Linear Regression.

\begin{tabular}{|c|c|c|c|c|c|c|}
\hline & \multicolumn{3}{|c|}{ Model 1} & \multicolumn{3}{|c|}{ Model 2} \\
\hline & Coef. & $95 \% \mathrm{Cl}$ & $\begin{array}{c}P \\
\text { value }\end{array}$ & Coef. & $95 \% \mathrm{Cl}$ & $\begin{array}{c}\mathrm{P} \\
\text { value }\end{array}$ \\
\hline $\begin{array}{l}\text { Socio- } \\
\text { economic and } \\
\text { Health care } \\
\text { conditions }\end{array}$ & & & & & & \\
\hline $\begin{array}{l}\text { Availability of } \\
\text { Electricity }\end{array}$ & 1.35 & $\begin{array}{c}(-2.2 \\
4.9)\end{array}$ & 0.410 & & & \\
\hline $\begin{array}{c}\text { Availability of } \\
\text { Safe Drinking } \\
\text { Water }\end{array}$ & 0.06 & $\begin{array}{c}(-1.2 \\
1.4)\end{array}$ & 0.921 & & & \\
\hline $\begin{array}{l}\text { Improved } \\
\text { sanitation } \\
\text { Facility }\end{array}$ & -2.14 & $\begin{array}{c}(-4.7 \\
0.4)\end{array}$ & 0.088 & $-2.07^{\star}$ & $\begin{array}{l}(-3.3 \\
-0.8)\end{array}$ & 0.003 \\
\hline $\begin{array}{c}\text { Use of Clean } \\
\text { Fuel }\end{array}$ & 1.69 & $\begin{array}{c}(-1.4 \\
4.8)\end{array}$ & 0.253 & & & \\
\hline $\begin{array}{c}\text { Health } \\
\text { Insurance } \\
\text { Coverage }\end{array}$ & 0.76 & $\begin{array}{c}(-1.7 \\
3.2)\end{array}$ & 0.496 & & & \\
\hline $\begin{array}{c}\text { Women } \\
\text { Literacy Rate }\end{array}$ & -1.95 & $\begin{array}{c}(-4.5 \\
0.6)\end{array}$ & 0.124 & $-1.39^{*}$ & $\begin{array}{l}(-2.7 \\
-0.1)\end{array}$ & 0.042 \\
\hline $\begin{array}{l}\text { Use of Family } \\
\text { Planning } \\
\text { Method }\end{array}$ & -0.40 & $\begin{array}{c}(-2.6 \\
1.8)\end{array}$ & 0.695 & & & \\
\hline Antenatal care & -0.38 & $\begin{array}{c}(-2.5 \\
1.7)\end{array}$ & 0.690 & & & \\
\hline $\begin{array}{l}\text { Institutional } \\
\text { births }\end{array}$ & -0.66 & $\begin{array}{c}(-3.7 \\
2.4)\end{array}$ & 0.631 & & & \\
\hline $\begin{array}{c}\text { Fully } \\
\text { Immunization }\end{array}$ & -0.75 & $\begin{array}{c}(-2.6 \\
1.1)\end{array}$ & 0.389 & -0.97 & $\begin{array}{c}(-2.1 \\
0.1)\end{array}$ & 0.080 \\
\hline Constant & 4.29 & $\begin{array}{l}(2.3 \\
6.2)\end{array}$ & 0.001 & 4.81 & $\begin{array}{l}(3.9 \\
5.7)\end{array}$ & 0.000 \\
\hline $\mathrm{R} 2$ & & 0.5987 & & & 0.7282 & \\
\hline $\mathrm{N}$ & & 20 & & & 20 & \\
\hline
\end{tabular}


with the child health (morbidity) status index. Model 2 suggests that index of improved sanitation facility, index of women literacy rate and index of full immunization explains 73 percent of the total variability of child morbidity composite index. For 1-unit increase in the index of improved sanitation facility, there is 2.1 units decrease in composite index of child morbidity. There is 1.4 units decrease in composite index of child morbidity with 1-unit increase in the index of index of women literacy rate.

\section{CONCLUSION}

The finding shows that among the districts of West Bengal North Twenty-Four Pargana district ranks first in socio-economic conditions and Puruliya district comes last. North Twenty-Four Pargana district in West Bengal is also showing a good health care status along with low child morbidity, whereas Puruliya district shows a poor health care status along with high child morbidity.

The result of rank-correlation between the socio-economic conditions and health care services with child morbidity are found to be negative. The present study also finds among socio-economic variables electricity availability, mother's literacy, use of improved sanitation facility reduce the risk of child morbidity. Moreover, child immunization is negatively correlated with child morbidity in West Bengal.

The present study identifies the districts with poor socio-economic conditions, low health care status and with resulting high child morbidity. The study also identifies the association of the child morbidity with socio-economic and health care status. It recommends to target the districts with high child morbidity and suggests that the incidence of the same can be reduced by improving socio-economic conditions along with the increased availability of good health care services.

\section{CONFLICT OF INTEREST}

The authors declare that there is no conflict of interest.

\section{ABBREVIATIONS}

DI: Dimension Index; SDG: Sustainable Development Goal; UNICEF: United Nations International Children's Emergency Fund; WHO: World Health Organization; ARI: Acute Respiratory Infection; NFHS: National Family Health Survey; MDG: Millennium Development Goal; RCH: Reproductive and Child Health Programme; NHM: National Health Mission; U5MR: Under 5 Mortality Rate; IMR: Infant Mortality Rate; MoHFW: Ministry of Health and Family Welfare; IIPS: International Institute for Population Sciences.

\section{REFERENCES}

1. Victora CG, Adair L, Fall C, Hallal PC, Martorell R, Richter L, et al. Maternal and Child Under nutrition Study Group. Maternal and child under nutrition: Consequences for adult health and human capital. The Lancet. 2008 Jan 26;371(9609):340-57.
2. Behrman JR, Calderon MC, Preston SH, Hoddinott J, Martorell R, Stein AD. Nutritional supplementation in girls influences the growth of their children: Prospective study in Guatemala. The American Journal of Clinical Nutrition. 2009;90(5):1372-9.

3. United Nations Children's Fund. Levels and trends of Child mortality: By United Nations Inter-agency Group for Child Mortality Estimation. UNICEF. 2019 https://www.unicef.org/media/60561/file/UN-IGME-child-mortality-report-2019. pdf

4. WHO, 2017. Causes of child death. 2017 https://www.who.int/data/gho/data/ themes/topics/indicator-groups/indicator-group-details/GHO/causes-of-childdeath

5. Neumann CG, Gewa C, Bwibo NO. Child nutrition in developing countries. Pediatric Annals. 2004;33(10):658-74

6. Chawla S, Goel AK, Thiyagarajan V, Nair NP. Nutritional assessment and its association with rotavirus positivity among under five children admitted with diarrhea in a tertiary care hospital of southern Haryana, India. The Indian Journal of Pediatrics. 2021;7:1-6

7. United Nations Children's Fund. Levels and trends in child mortality, 2011 report. New York: UNICEF. 2011. Available at: https://www.unicef.org/media/files/ Child_Mortality_Report_2011_Final.pdf.

8. Liu L, Johnson HL, Cousens S, Perin J, Scott S, Lawn JE, et al. Global, regional, and national causes of child mortality: An updated systematic analysis for 2010 with time trends since 2000. The Lancet. 2012;379(9832):2151-61.

9. Black RE, Victora CG, Walker SP, Bhutta ZA, Christian P, Onis DM, et al. Mater nal and child undernutrition and overweight in low-income and middle-income countries. The Lancet. 2013;382(9890):427-51.

10. Medrano P, Rodríguez C, Villa E. Does mother's education matter in child's health? Evidence from South Africa 1. South African Journal of Economics. 2008;76(4):612-27

11. Mallick R. Impact of Socio-Economic Variables and Child Health Care on UnderFive Child Health Status in West Bengal, India. Journal Homepage: www. ijrpr. com ISSN.;2582:7421.

12. International Institute for Population Sciences. National Family Health Survey (NFHS-3), 2005-06, India Fact Sheet. Mumbai: IIPS. 2007. Available at: http:// www.rchiips.org/nfhs/ report.shtml. Accessed 02 Mar 2021

13. International Institute for Population Sciences. National Family Health Survey (NFHS-4), 2015-16, India Fact Sheet. Mumbai: IIPS. 2017. Available at: http:// rchiips.org/nfhs/ factsheet_NFHS-4.shtml. Accessed 02 Mar 2021.

14. Mulholland K. Childhood pneumonia mortality: A permanent global emergency. The Lancet. 2007;370(9583):285-9.

15. Anand K, Sundaram KR, Lobo J, Kapoor SK. Are diarrheal incidence and malnutrition related in under five children? A longitudinal study in an area of poor sanitary conditions. Indian Pediatrics. 1994;31(8):943-8.

16. Black RE, Cousens S, Johnson HL, Lawn JE, Rudan I, Bassani DG, et al. Global regional, and national causes of child mortality in 2008: A systematic analysis. The Lancet. 2010;375(9730):1969-87.

17. Paramanik D, Datta S, Pal P, Chowdhury S, Murmu J, Nayek S. Assessment of Morbidity Profile of Under-Five Children in a Rural Area of West Bengal. Indian Journal of Hygiene and Public health. 2015;46:45-5.

18. Farhad J, Malihe A, Fatemeh A, Mahmood S. The knowledge, attitude and practice of mothers regarding acute respiratory tract Infection in children. Biosciences Biotechnology Research Asia. 2014

19. Chan GC, Tang SF. Parental knowledge, attitudes and antibiotic use for acute upper respiratory tract infection in children attending a primary healthcare clinic in Malaysia. Malaysian Family Physician. 2012;2(1):5.

20. SDGs Goal: https://www.undp.org/content/undp/en/home/sustainabledevelopment-goals/goal-3-good-health-and-well-being.html

21. Chaikaew N, Tripathi NK, Souris M. Exploring spatial patterns and hotspots of diarrhea in Chiang Mai, Thailand. International Journal of Health Geographics. 2009;8(1):1-0.

22. International Institute for Population Sciences. National Family Health Survey (NFHS-5), 2019-2020, India Fact Sheet. Mumbai: IIPS. 2020. Available at: http:// rchiips.org/nfhs/NFHS-5_FCTS/FactSheet_WB.pdf . 